\title{
PENINGKATAN HASIL BELAJAR BIOLOGI SISWA DENGAN MENGGUNAKAN METODE TUTORIAL TEMAN SEBAYA PADA SISWA KELAS XII IPS 3 SMA NEGERI 1 KAYUAGUNG
}

\author{
Nurlailah \\ Guru SMA Negeri 1 Kayuagung \\ nurlailah@gmail.com
}

\begin{abstract}
ABSTRAK
Penelitian tindakan kelas ini bertujuan untuk meningkatkan hasil belajar Biologi dengan manfaatnya untuk mendapat teori-teori baru tentang peningkatan hasil belajar siswa. Kegiatan ini menggunakan metode penelitian tindakan kelas yang dilaksanakan 2 siklus. Sebagai subjek penelitian siswa kelas XII IPS 3 SMA Negeri 1 Kayuagung berjumlah 35 orang. Data dikumpulkan dengan menggunakan instrumen tes, lembar observasi dan lembar wawancara sedangkan teknik pengumpulan data dilakukan dengan melaksanakan pengukuran hasil belajar siswa dari setiap siklus dan hasil observasi yang dideskripsikan. Analisis data dilakukan secara deskriptif kualitatif yang menggambarkan ketuntasan belajar siswa, keberhasilan dan kegagalan pembelajaran serta kelancaran dan kendala siswa dalam pembelajaran. Sedangkan indikator kinerja dalam penelitian ini meningkatnya ketuntasan belajar siswa mencapai $85 \%$. Prosedur yang digunakan dalam penelitian ini sesuai dengan metoda penelitian tindakan kelas yang menggunakan siklus dilaksanakan mulai dari perencanaan, pelaksanaan observasi dan refleksi. Hasil dari penelitian ini menunjukkan bahwa terjadinya peningkatan hasil belajar siswa dengan ketuntasan 53,13\% pada siklus 1 , siklus II dengan ketuntasan 88,57\%.
\end{abstract}

Kata Kunci: Hasil Belajar,Biologi, Metode Tutorial Teman Sebaya

\section{ABSTRACT}

This classroom action research aims to improve biology learning outcomes with the benefit of obtaining new theories about improving student learning outcomes. This activity uses a classroom action research method carried out in 2 cycles. As the research subject, the students of class XII IPS 3 at SMA Negeri 1 Kayuagung were 35 people. Data were collected using test instruments, observation sheets and interview sheets, while data collection techniques were carried out by measuring student learning outcomes from each cycle and described observation results. Data analysis was carried out in a descriptive qualitative manner which describes the students' learning completeness, the success and failure of learning as well as the fluency and constraints of students in learning. While the performance indicators in this study increased students' learning completeness to reach $85 \%$. The procedure used in this study is in accordance with the classroom action research method using cycles carried out from planning, implementing observation and reflection. The results of this study indicate that there is an increase in student learning outcomes with $53.13 \%$ completeness in cycle 1, cycle II with completeness $88.57 \%$.

Keywords: Learning Outcomes, Biology, Peer Tutorial Method 


\section{PENDAHULUAN}

Biologi merupakan salah satu kelompok ilmu pengetahuan alam dengan objek dan permasalahan yang berkaitan dengan fenomena alam dan berbagai permasalahan dalam kehidupan. Pembelajaran lebih banyak berpusat pada siswa dan guru lebih berperan sebagai fasilitator. Sebagai fasilitator guru harus mampu menciptakan kegiatan pembelajaran yang mengaktifkan siswa dalam berpikir dan bersikap ilmiah (Mulyasa 2006).

Proses pembelajaran tidak selalu tergantung pada keberadaan guru (pendidik) sebagai pengelola proses pembelajaran. Hal ini didasarkan pada hakekat proses belajar yaitu interaksi antara peserta didik dengan objek yang dipelajari. Oleh karena itu, peranan sumber dan media belajar tidak dapat dikesampingkan, khususnya peranan sumber belajar Biologi sebagai salah satu komponen masukan instrumental dapat tersedia di dalam maupun di luar sekolah (Suhardi, 2008).

Sumber belajar Biologi tidak hanya terbatas yang terprogram, seperti laboratorium atau praktikum, melainkan lingkungan siswa mulai dari lingkungan siswa itu sendiri sampai lingkungan yang jauh dari dirinya. Lingkungan dapat menjadi sumber belajar siswa dan dapat menimbulkan aktivitas belajar siswa.

Berdasarkan pengamatan yang dilakukan di kelas XII IPS 3 SMA Negeri 1 Kayuagung bahwa hasil belajar peserta didik khususnya pada mata pelajaran Biologi masih belum memenuhi Kriteria Ketuntasan Minimum (KKM). Data daftar nilai ulangan harian yang diperoleh peserta didik pada mata pelajaran Biologi menunjukkan $45 \%$ peserta didik mendapatkan nilai $\geq 75$ sedangkan sisanya $55 \%$ peserta didik mendapatkan nilai $<75$. Itu artinya hampir setengah dari jumlah peserta didik belum mencapai KKM. Sedangkan untuk mencapai standart KKM peserta didik harus mendapatkan nilai $\geq 75$. Secara klasikal peserta didik peserta didik dikatakan tuntas belajar apabila $85 \%$ dari jumlah peserta didik memperoleh nilai $\geq 75$, sebaliknya peserta didik dikatakan belum tuntas belajar apabila memperoleh nilai < 
75. Salah satu penyebabnya adalah pembelajaran yang dilakukan merupakan pembelajaran konvensional, sehingga peserta didik kurang dapat memahami secara luas pokok bahasan yang diberikan guru, peserta didik kurang antusias dalam pembelajaran ini menyebabkan tidak termotivasinya peserta didik dan kurang berkembangnya kreatifitas serta keterampilan peserta didik.

Sehubungan dengan hal tersebut perlu adanya suatu pembelajaran dengan pendekatan atau metode tertentu yang dapat meningkatkan kemampuan peserta didik dan hasil belajar peserta didik. Pada penelitian ini akan diterapkan metode kooperatif Pembelajaran Kooperatif Teman Sebaya. Pembelajaran ini pada prinsipnya adalah mengembangkan perangkat yang pembelajarannya dirancang dengan metode kooperatif Pembelajaran Kooperatif Teman Sebaya.

Berangkat dari paparan di atas, maka dipandang perlu dilakukan uji coba pembelajaran dengan melakukan penelitian tindakan kelas dengan judul "Peningkatan Hasil Belajar Biologi
Siswa Dengan Menggunakan Metode Tutorial Teman Sebaya Pada Siswa Kelas XII IPS 3 SMA Negeri 1 Kayuagung Tahun Pelajaran 2019/2020 ". Adapun rumusan masalah pada penelitian ini adalah: “Apakah hasil belajar siswa pada mata pelajaran Biologi dapat meningkat dengan menggunakan metode Tutorial Teman Sebaya pada siswa kelas XII IPS 3?

Belajar adalah sebuah proses yang dilakukan oleh individu untuk memperoleh sebuah perubahan tingkah laku yang menetap, baik yang dapat diamati maupun yang tidak dapat diamati secara langsung, yang terjadi sebagai suatu hasil latihan atau pengalaman dalan interaksinya dengan lingkungan (Roziqin, 2007: 62).

Menurut UU Nomor 20 Tahun 2003 tentang Sisdiknas, pembelajaran adalah proses interaksi peserta didik dengan pendidik dan sumber belajar pada suatu lingkungan belajar. Menurut Gagne, Briggs dan Wagner dalam Udin S. Winataputra (2008) pengertian pembelajaran adalah serangkaian kegiatan yang dirancang untuk memungkinkan terjadinya proses 
belajar pada siswa. Dapat disimpulkan bahwa pembelajaran adalah upaya yang dilakukan untuk membantu seseorang atau sekelompok orang dalam melakukan kegiatan pembelajaran dengan menggunakan cara yang terstruktur dan efisien sehingga dapat mencapai tujuan pembelajaran secara maksimal.

Hasil pembelajaran adalah semua efek yang dapat dijadikan sebagai indikator tentang nilai dari penggunaan strategi pembelajaran. Penilaian hasil belajar bertujuan melihat kemajuan hasil belajar peserta didik dalam hal penguasaan materi pengajaran yang telah dipelajarinya dengan tujuan-tujuan yang telah ditetapkan.

Menurut Slameto (2008:7) "hasil belajar adalah sesuatu yang diperoleh dari suatu proses usaha setelah melakukan kegiatan belajar yang dapat diukur dengan menggunakan tes guna melihat kemajuan siswa". Lebih lanjut Slameto (2008:8) mengemukakan bahwa "hasil belajar diukur dengan rata-rata hasil tes yang diberikan dan tes hasil belajar itu sendiri adalah sekelompok pertanyaan atau tugas- tugas yang harus dijawab atau diselesaikan oleh siswa dengan tujuan mengukur kemajuan belajar siswa".

Pada umumnya hasil belajar dapat dikelompokkan menjadi tiga ranah, yaitu kognitif, afektif, dan psikomotor. Maka ranah-ranah tersebut dapat diuraikan sebagai berikut:

a. Ranah kognitif, adalah tujuan pendidikan yang berhubungan dengan kemampuan intelektual atau kemampuan berpikir, seperti kemampuan mengingat dan kemampuan memecahkan masalah. Domain kognitif menurut Bloom terdiri dari enam tingkatan yaitu pengetahuan, pemahaman, aplikasi, analisis, sintesis, dan evaluasi

b. Ranah afektif, berkenaan dengan sikap, nilai-nilai, dan apresiasi. Ada lima tingkatan dalam ranah afektif ini yaitu penerimaan, merespons, menghargai, organisasi, dan pola hidup

c. Ranah psikomotor, meliputi semua tingkah laku yang menggunakan syaraf dan otot badan. Ada lima tingkatan dalam ranah ini, yaitu imitasi, manipulasi, presisi, 
artikulasi, dan naturalisasi (Sanjaya, 2009:127-128).

Menurut Djamarah dan Zain (2006: 107) "yang menjadi petunjuk bahwa suatu proses belajar mengajar dianggap berhasil adalah daya serap terhadap bahan pelajaran yang diajarkan mencapai prestasi tinggi baik secara individual maupun kelompok.

Gagne (Dimyati dan Mudjiono, 2008:2) menyatakan bahwa 'terdapat lima kemampuan yang diperoleh dari proses belajar mengajar yang dapat diamati tentang hasil belajar, yaitu:

a. Keterampilan intelektual

b. Kemampuan penguasaan strategi kognitif

c. Kemampuan informasi verbal

d. Kemampuan yang berhubunngan dengan sikap (afektif)

e. Kemampuan yang berhubungan dengan keterampilan kerja.

Dimyati dan Mudjiono (2008:3) menyatakan bahwa hasil belajar merupakan hasil dari interaksi tindakan belajar dan tindakan mengajar dan dari sisi guru, tindakan diakhiri dengan proses evaluasi hasil belajar sedangkan dari siswa, hasil belajar merupakan berkhirnnya pengalaman belajar. Sementara itu, Oemar Hamalik

(2008:36) mengatakan bahwa "hasil belajar bukan suatu penguasaan hasil latihan, melainkan perubahan kelakuan".

Arends (Suyitno, 2011:33) mengemukakan bahwa "ada tiga hasil belajar yang diperoleh pelajar yang diajar dengan menggunakan model pembelajaran berbasis masalah, yaitu inkuiri keterampilan memecahkan masalah, belajar model peraturan orang dewasa, dan keterampilan belajar mandiri".

Pembelajaran adalah proses interaksi peserta didik dengan pendidik dan sumber belajar pada suatu lingkungan belajar. Pembelajaran merupakan usaha sengaja, terarah dan bertujuan agar orang lain dapat memperoleh pengalaman yang bermakna (BSNP, 2006: 30). Pembelajaran Biologi di sekolah menengah diharapkan dapat menjadi wahana bagi peserta didik untuk mempelajari diri sendiri dan alam sekitar serta proses pengembangan lebih lanjut dalam penerapannya di kehidupan seharihari. Penting sekali bagi setiap guru 
memahami sebaik-baiknya tentang proses belajar siswa, agar dapat memberikan bimbingan dan menyediakan lingkungan belajar yang tepat dan serasi bagi siswa (Oemar Hamalik, 2010:36).

Biologi sebagai ilmu memiliki kekhasan tersendiri dibandingkan dengan ilmu-ilmu yang lain. Biologi merupakan salah satu ilmu pengetahuan yang mempelajari makhluk hidup dan kehidupannya dari berbagai aspek persoalan dan tingkat organisasinya. Produk keilmuan Biologi berwujud kumpulan faktafakta maupun konsep-konsep sebagai hasil dari proses keilmuan Biologi (Sudjoko, 2001:2).

Pembelajaran Biologi pada hakikatnya merupakan suatu proses untuk menghantarkan siswa ke tujuan belajarnya, dan Biologi itu sendiri berperan sebagai alat untuk mencapai tujuan tersebut. Biologi sebagai ilmu dapat diidentifikasikan melalui objek, benda alam, persoalan/gejala yang ditunjukkan oleh alam, serta proses keilmuan dalam menemukan konsep-konsep Biologi.
Metode Pembelajaran Tutorial Teman Sebaya adalah metode pembelajaran yang menitikberatkan kepada kemampuan menjalin komunikasi yang baik antar sesama siswa dalam mengungkapkan ide-ide ataupun pemikiran-pemikiran yang di miliki siswa pada saat pembelajaran berlangsung. Untuk mendapatkan hasil yang baik pada metode pembelajaran Tutorial Teman Sebaya siswa di tuntut untuk dapat mendengarkan dengan baik penjelasan guru serta harus fokus dan berkonsentrasi pada proses pembelajaran yang sedang berlangsung.

Salah satu metode yang dapat digunakan oleh guru dalam kegiatan pembelajaran adalah metode tutorial sebaya. Tutorial sebaya yang dalam istilah bahasa Inggris sering disebut dengan peer teaching merupakan metode yang mengajak siswa untuk belajar dengan teman sebayanya. Menurut Syaiful Bahri Djamarah dan Aswan Zain (2006: 25) disebut tutorial sebaya karena yang menjadi pengajar mempunyai usia yang hampir sebaya dengan siswa yang diajar. Jadi, tutorial sebaya merupakan metode yang 
memfasilitasi siswa untuk belajar dengan teman sebayanya, saat pembelajaran siswa diajar oleh teman yang usianya hampir sebaya dengan siswa tersebut.

Menurut Silbermen (2001) bahwa Tutor sebaya merupakan salah satu dari strategi pembelajaran yang berbasis active learning. Beberapa ahli percaya bahwa satu pelajaran benar-benar dikuasai hanya apabila peserta didik mampu mengajarkan pada peserta didik lainnya. Mengajar teman sebaya memberikan kesempatan dan mendorong pada peserta didik mempelajari sesuatu dengan baik, dan pada waktu yang sama ia menjadi narasumber bagi yang lain. Pembelajaran peer teaching merupakan cara yang efektif untuk menghasilkan kemampuan mengajar teman sebaya.

\section{METODE PENELITIAN}

Penelitian ini merupakan tindakan kelas (Classroom Action Research), bertujuan untuk memecahkan masalah-masalah melalui penerapan langsung di kelas atau tempat kerja. Subyek penelitian adalah siswa kelas XII IPS 3 SMA Negeri 1 Kayuagung yang berjumlah 35 siswa dan peneliti adalah guru yang mengampu mata pelajaran Biologi tersebut. Penerapan penelitian ini diterapkan dalam pokok bahasan Pertumbuhan dan Perkembangan.

Tempat penelitian adalah tempat yang digunakan dalam melakukan penelitian untuk memperoleh data yang diinginkan. Penelitian ini bertempat di SMA Negeri 1 Kayuagung yang beralamat di Jalan Letnan Muchtar Saleh No.7, Kayuagung, Paku, Kec. Kayuagung, Kabupaten Ogan Komering Ilir, Sumatera Selatan 30867. Penelitian dilakukan pada waktu pembelajaran semester ganjil tahun pelajaran 2019 -2020, tepatnya pada bulan September 2019 sampai dengan bulan November 2019. Pada penelitian ini yang menjadi subjek adalah siswa kelas XII IPS 3 SMA Negeri 1 Kayuagung yang berjumlah 35 siswa.

\section{HASIL DAN PEMBAHASAN}

\section{Siklus I}

Pelaksanaan kegiatan belajar mengajar untuk siklus I dilaksanakan pada tanggal 5 September 2019 di kelas XII IPS 3 dengan jumlah siswa 35 siswa. Pelaksanaan model pembelajaran kooperatif tipe 
Kooperatif Tutorial Teman Sebaya melalui tahapan sebagai berikut : (1)

Pelaksanaan pembelajaran,

Diskusi kelompok, (3) Tes, (4)

Penghargaan kelompok,

Menentukan nilai individual dan kelompok. Dalam hal ini peneliti bertindak sebagai pengajar, sedangkan yang bertindak sebagai pengamat adalah seorang guru Biologi dan Wali Kelas XII IPS 3 SMA Negeri 1 Kayuagung . Adapun proses belajar mengajar mengacu pada rencana pembelajaran yang telah dipersiapkan. Pengamatan (observasi) dilaksanakan bersamaan dengan pelaksanaan dengan pelaksanaan belajar mengajar. Pada akhir proses belajar mengajar siswa diberi tes formatif I dengan tujuan untuk mengetahui tingkat keberhasilan siswa dalam proses belajar mengajar yang telah dilakukan. Adapun data hasil penelitian pada siklus I adalah sebagi berikut :

\section{Tabel 1 Hasil Tes Pada Siklus I}

\begin{tabular}{|c|l|c|}
\hline No. & \multicolumn{1}{|c|}{ Uraian } & Siklus I \\
\hline \hline 1. & $\begin{array}{l}\text { Nilai rata-rata tes } \\
\text { formatif }\end{array}$ & 65,26 \\
\hline 2. & $\begin{array}{l}\text { Jumlah siswa yang } \\
\text { tuntas belajar }\end{array}$ & 17 \\
\hline 3. & $\begin{array}{l}\text { Persentase ketuntasan } \\
\text { belajar }\end{array}$ & 53,13 \\
\hline
\end{tabular}

Dari tabel di atas dapat dijelaskan bahwa dengan menerapkan model pembelajaran kooperatif tipe Kooperatif Tutorial Teman Sebaya Berbasis Kontekstual diperoleh nilai rata-rata hasil belajar siswa adalah ketuntasan belajar mencapai 53,13\% atau ada 17 siswa dari 35 siswa sudah tuntas belajar. Hasil tersebut menunjukkan bahwa pada siklus pertama secara klasikal siswa belum tuntas belajar, karena siswa yang memperoleh nilai $\geq 75$ hanya sebesar 53,13\% lebih kecil dari presentase ketuntasan yang dikehendaki yaitu sebesar $85 \%$. Hal ini disebabkan karena siswa masih merasa baru dan belum mengerti apa yang dimaksudkan dan digunakan guru dengan menerapkan model pembelajaran kooperatif tipe Kooperatif Tutorial Teman Sebaya Berbasis Kontekstual.

Dalam pelaksanaan kegiatan belajar mengajar diperoleh informasi dari hasil pengamatan sebagai berikut :Guru kurang maksimal dalam memotivasi siswa dan dalam menyampaikan tujuan pembelajaran. Guru kurang maksimal dalam pengelolaan waktu Siswa kurang 
aktif selama pembelajaran berlangsung.

\section{Siklus II}

Pelaksanaan kegiatan belajar mengajar untuk siklus II dilaksanakan pada tanggal 29 September 2018 di Kelas XII IPS 3 SMA Negeri 1 Kayuagung yang berjumlah 35 siswa. Pelaksanan model pembelajaran kooperatif tipe Kooperatif Tutorial Teman Sebaya Berbasis Kontekstual melalui tahapan sebagai berikut;

Pelaksanaan pembelajran,

Diskusi klompok, (3) Tes,

Penghargaan kelompok,

Menentukan nilai individual dan kelompok. Dalam hal ini peneliti bertindak sebagai pengajar, sedangkan yang bertindak sebagai pengamat adalah seorang guru Biologi dan Wali Kelas XII IPS 3 SMA Negeri 1 Kayuagung . Adapun proses belajar mengajar mengacu pada rencana pelajaran dengan memperhatikan revisi pada siklus I, sehingga kesalahan atau kekurangan pada siklus I tidak terulang lagi pada siklus II. Pengamatan (observasi) dilaksanakan bersamaan dengan pelaksanaan belajar mengajar. Pada akhir proses belajar mengajar siswa diberi tes formatif II dengan tujuan untuk mengetahui tingkat keberhasilan siswa dalam proses belajar mengajar yang telah dilakukan. Instrument yang digunakan adalah tes formatif II.

Berikut adalah rekapitulasi hasil tes formatif siswa terlihat pada tabel:

Tabel 2. Hasil Tes Siklus II

\begin{tabular}{|c|l|c|}
\hline No. & \multicolumn{1}{|c|}{ Uraian } & $\begin{array}{c}\text { Hasil } \\
\text { Siklus II }\end{array}$ \\
\hline \hline 1. & $\begin{array}{l}\text { Nilai rata-rata tes } \\
\text { formatif }\end{array}$ & 85,54 \\
\hline 2. & $\begin{array}{l}\text { Jumlah siswa yang } \\
\text { tuntas belajar }\end{array}$ & 31 \\
\hline 3. & $\begin{array}{l}\text { Persentase } \\
\text { ketuntasan belajar }\end{array}$ & 88,57 \\
\hline
\end{tabular}

Dari tabel diatas diperoleh nilai rata-rata hasil belajar siswa adalah 85,54 dan ketuntasan belajar mencapai $88,57 \%$ atau ada 31 siswa dari 35 siswa sudah tuntas belajar. Hasil ini menunjukkan bahwa pada siklus II ini ketuntasan belajar secara klasikal telah mengalami peningkatan lebih baik dari siklus I. Adanya peningkatan hasil belajar siswa ini karena setelah guru menginformasikan bahwa setiap akhir pelajaran akan selalu diadakan tes sehingga pada pertemuan berikutnya siswa lebih termotivasi untuk belajar. Selain itu siswa juga sudah mulai mengerti apa yang 
dimaksudkan dan diinginkan guru dengan menerapkan model pembelajaran kooperatif tipe Kooperatif Tutorial Teman Sebaya . Pelaksanan kegiatan belajar pada Siklus II ini sudah berjalan dengan baik siswa sudah mulai mengerti dengan apa yang dimaksudkan oleh guru. Secara klasikal ketuntasan belajar pada siklus II telah tercapai maka penelitian ini hanya dilakukan sampai siklus II saja.

\section{Pembahasan}

Melalui hasil penelitian ini menunjukkan bahwa model pembelajaran kooperatif tipe Kooperatif Tutorial Teman Sebaya Berbasis Kontekstual memiliki dampak positif dalam meningkatkan hasil belajar siswa. Hal ini dapat dilihat dari semakin mantapnya pemahaman siswa terhadap materi yang disampaikan guru (ketuntasan belajar meningkat dari siklus I, dan II ) yaitu masing-masing $53,13 \%$ dan $88,57 \%$. Ketuntasan belajar siswa secara klasikal telah tercapai Kemampuan guru dalam mengelola pembelajaran.

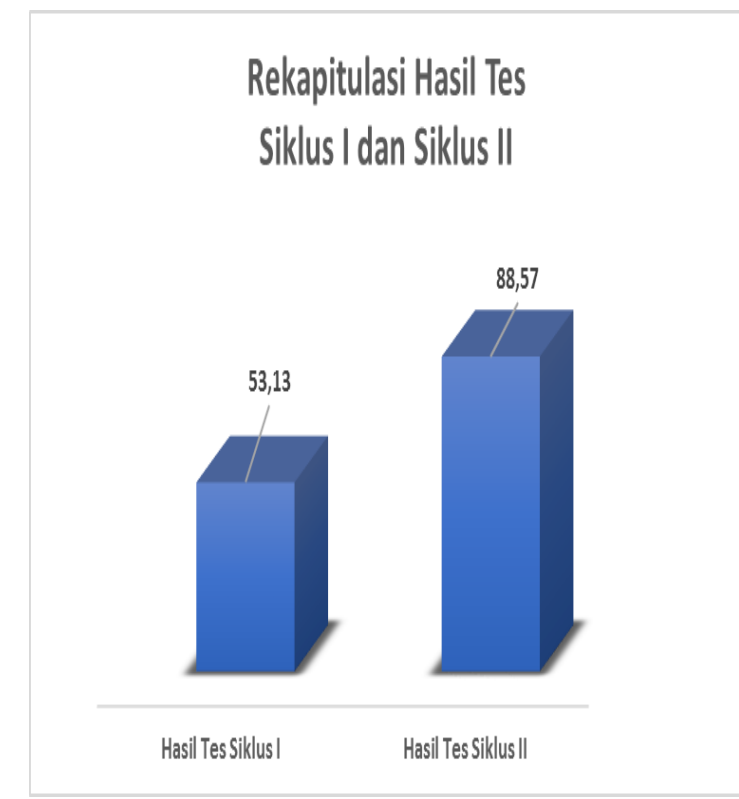

Berdasarkan analisis data, diperoleh aktifitas siswa dalam proses belajar mengajar dengan menerapkan model pembelajaran kooperatif tipe Kooperatif Tutorial Teman Sebaya Berbasis Kontekstual dalam setiap siklus mengalami peningkatan. Hal ini berdampak positif terhadap hasil belajar siswa yaitu dapat ditunjukkan dengan meningkatnya nilai rata-rata siswa pada setiap siklus yang terus mengalami peningkatan.

Berdasarkan analisis data, diperoleh aktivitas siswa dalam proses pembelajaran dengan pemberian tugas dalam setiap siklus mengalami peningkatan. Hal ini berdampak positif terhadap proses pembelajaran mengingat kembali 
materi pelajaran yang telah diterima selama ini, yaitu dapat ditunjukkan dengan meningkatnya nilai rata-rata siswa pada setiap siklus yang terus mengalami peningkatan. Berdasakan analisis data, diperoleh aktifitas siswa dalam proses pembelajaran perbaikan dan setting ulang koneksi jaringan pada pokok bahasan Melakukan perbaikan konektifitas jaringan dengan model pembelajaran kooperatif tipe Kooperatif Tutorial Teman Sebaya Berbasis Kontekstual yang paling dominan adalah bekerja dengan sesama anggota kelompok, mendengarkan/ memperhatikan penjelasan guru dan diskusi antar siswa /antara siswa dengan guru. Jadi dapat dikatakan bahwa aktifitas siswa dikategorikan aktif. Sedangkan untuk aktifitas guru selama pembelajaran telah melaksanakan langkah-langkah kegiatan belajar mengajar dan menerapkan pengajaran konstektual tipe pengajaran berbasis masalah dengan baik. Hal ini terlihat dari aktivitas guru yang muncul, diantaranya aktivitas membimbing dan mengamati siswa dalam menemukan konsep, menjelaskan materi yang sulit, memberi umpan balik/ evaluasi/ tanya jawab dimana presentase untuk aktivitas di atas cukup besar.

\section{SIMPULAN}

Berdasarkan hasil penelitian yang telah dipaparkan selama dua siklus, hasil seluruh pembahasan serta analisis yang telah dilakukan dapat disimpulkan bahwa Model pembelajaran kooperatif tipe Kooperatif Tutorial Teman Sebaya Berbasis Kontekstual memiliki dampak positif dalam meningkatkan hasil belajar siswa yang ditandai dengan peningkatan ketuntasan belajar siswa dalam setiap siklus, yaitu siklus I (53,13\%), siklus II (88,57\%), Model pembelajaran kooperatif tipe Kooperatif Tutorial Teman Sebaya Berbasis Kontekstual dapat menjadikan siswa merasa dirinya mendapat perhatian dan kesempatan untuk menyampaikan pendapat, gagasan, ide, dan pertanyaan. Penerapan model pembelajaran kooperatif tipe Kooperatif Tutorial Teman Sebaya Berbasis Kontekstual mempunyai pengaruh positif, yaitu dapat meningkatkan motivasi belajar siswa.

Dari hasil penelitian yang diperoleh dari uraian sebelum agar 
proses belajar mengajar perbaikan dan setting ulang koneksi jaringan lebih efektif dan lebih memberikan hasil yang optimal bagi siswa, maka disampaikan saran sebagai berikut:Untuk melaksanakan model pembelajaran kooperatif tipe Kooperatif Tutorial Teman Sebaya Berbasis Kontekstual memerlukan persiapan yang cukup matang, sehingga guru harus mampu menentukan atau memilih topik yang benar-benar bisa diterapkan dengan Model pembelajaran kooperatif tipe Kooperatif Tutorial Teman Sebaya Berbasis Kontekstual dalam proses belajar mengajar sehingga memperoleh hasil yang optimal. Dalam rangka meningkatkan hasil belajar siswa, guru hendaknya lebih sering melatih siswa dengan berbagai model pengajaran, walau dalam taraf yang sederhana, dimana siswa nantinya dapat menemukan pengetahuan baru, memperoleh konsep dan keterampilan, sehingga siswa berhasil atau mampu memecahkan masalah-masalah yang dihadapi. Perlu adanya penelitian yang lebih lanjut, karena hasil penelitian ini hanya dilakukan dikelas XII IPS 3 SMA Negeri 1

Kayuagung .

\section{DAFTAR PUSTAKA}

BSNP. 2006. Permendiknas RI No. 22 Tahun 2006 tentang Standar Isi untuk Satuan Pendidikan Dasar dan Menengah. Jakarta.

Dimyati dan Mudjiono, 2006. Belajar dan Pembelajaran. Jakarta: Rineka Cipta.

Dimyati dan Mudjiono. 2008. Belajar dan Pembelajaran. Jakarta: PT. Rineka Cipta

Djamarah dan Zain. (2006). Strategi Belajar Mengajar. Jakarta: Rineka Cipta

Hamalik, Oemar. (2010). Perencanaan Pengajaran Berdasarkan Pendekaan Sistem. Bandung: Bumi Aksara

Mel Siberrnen. 2001. Strategi Pembelajaran Aktif (Active Learning), terj. Sarjuli dan Azfat Ammar, Jakarta: Yakpendis

Mulyasa E. 2006. Menjadi Guru Profesional. Bandung: PT. Remaja Rosdakarya.

Roziqin, Muhammad Zainur. 2007. Moral Pendidikan di Era Global; Pergeseran Pola Interkasi Guru-Murid di Era Global. Malang: Averroes Press. Science Educator, 2,19. 
Slameto. (2008). Proses Belajar

Mengajar. Jakarta: Remaja

Rosdakarya.

Sudjoko.2001.Membantu siswa

Belajar IPA. Yogyakarta: FMIPA

UNY

Suhardi, 2008. Sintaksis.

Yogyakarta: UNY Press.

Suyitno, A., (2011), Dasar-dasar dan Proses Pembelajaran Matematika I, FMIPA UNNES, Semarang.

Wina Sanjaya . 2009 Strategi

Pembelajaran, Jakarta :

Kencana

Winataputra, Udin. (2008). Materidan Pembelajaran IPS SD. Jakarta: Universitas Terbuka. 
Nurlailah ,Peningkatan Hasil Belajar,,, 